\title{
Conversion of Methanol Using Modified H-MOR Zeolite Catalysts
}

\author{
Sameh M. K. ABOUL-FOTOUH ${ }^{1,{ }^{*}}$, Noha A. K. ABOUL-GHEIT ${ }^{2}$, Marwa M. I. HASSAN ${ }^{1}$ \\ ${ }^{1}$ Chemistry Department, Faculty of Education, Ain-Shams University, Roxy, Cairo, Egypt \\ ${ }^{2}$ Process Development Department, Egyptian Petroleum Research Institute, Cairo, Egypt
}

\begin{abstract}
The conversion of methanol was carried out over various mordenite zeolite catalysts to evaluate their catalytic performance. A post-preparation treatment of the $\mathrm{H}-\mathrm{MOR}$ catalyst by halogenation with $\mathrm{NH}_{4} \mathrm{Cl}$ or $\mathrm{NH}_{4} \mathrm{~F}$ and by hydrohalogenation with $\mathrm{HCl}$ or $\mathrm{HF}$ was carried out and its effect on methanol conversion reactions at $100-300{ }^{\circ} \mathrm{C}$ in a continuous flow reactor was investigated. The as-synthesized $\mathrm{H}-$ mordenite (H-MOR) is generally more active during dimethyl ether (DME) production than the $\mathrm{NH}_{4}-\mathrm{MOR}$ and Na-MOR. Fluorinated treatment with $\mathrm{HF}$ or $\mathrm{NH}_{4} \mathrm{~F}$ significantly improved the catalytic activity during methanol conversion and the formation of DME in comparison to chlorinated treatments with $\mathrm{HCl}$ or $\mathrm{NH}_{4} \mathrm{Cl}$. This is principally attributed to the higher $\mathrm{Si} / \mathrm{Al}$ ratio and an increase in the number of acid sites and their strength. Halogenation treatment with the acids of both $\mathrm{F}^{-}$or $\mathrm{Cl}^{-}$gave the highest conversion activity for DME production compared to halogenation treatments with the salts of the same halogens. Zeolite dealumination by the acids was more profound than that by the halogen ion salts, which resulted in a decrease in the crystallinity and crystallite sizes of the zeolite.
\end{abstract}

Key words: methanol; conversion; H-MOR; halogenation; hydrohalogenation

CLC number: O643 Document code: A

Methanol will possibly be one of the main fuels used in future when the petroleum resources are depleted. Methanol is produced from synthesis gas (mixture of $\mathrm{CO}_{2}$ and $\mathrm{H}_{2}$ ), which is formed by the steam reforming of natural gas, the gasification of coal or from biomass. Methanol is abundant and, therefore, it has been used as a raw material for the production of gasoline and olefins. It can be obtained from renewable sources such as biomass. The catalytic conversion of methanol to gasoline and to olefins attracted the attention of many researchers when the price of fuel started to increase. Literature concerning the conversion of methanol to hydrocarbons over zeolite catalysts is extensive [1-12]. Its nature and the extent of the reaction depend on the acid site density and strength as well as the reaction conditions [13-16].

Metal/metal oxide incorporation on to the surfaces of zeolites leads to an increase in methanol conversion and dimethyl ether (DME) yield [17-21]. If the metal is supported on $\mathrm{Al}_{2} \mathrm{O}_{3}$ [22], the acid sites are of the weak Lewis type where the acid strength is not strong enough to promote methoxonium ion formation and hence the dehydration reaction cannot occur. However, the H-forms of the zeolites possess strong Brönsted acid and Lewis sites that promote methanol conversion to DME and olefins and their reaction schemes are complicated. Nevertheless, treatment of cation-exchanged zeolites with $\mathrm{HCl}$ or $\mathrm{HF}$ leads to decationation and partial dealumination. The hydroconversion of cyclohexene over metal $/ \mathrm{Al}_{2} \mathrm{O}_{3}$ with and without $\mathrm{Cl}^{-}$and $\mathrm{F}$ ions has been studied by Aboul-Fotouh and Aboul-Gheit [23]. Introducing $\mathrm{Cl}^{-}$or $\mathrm{F}^{-}$ions into aluminate alumina in different ways causes Brönsted acid sites to appear and a drastic increase in both the skeletal isomerization and total conversion. Arena et al. [24] indicated that $\mathrm{Cl}^{-}$adsorbed on the surface of $\gamma$-alumina results in promotion because of a substantial change in the electronic properties of the outermost alumina layer. Ultimately, these effects result in a weakening of the $\mathrm{O}-\mathrm{H}$ bond, which renders the proton more acidic.

Doping H-ZSM-5 with a low concentration of $\mathrm{F}^{-}$followed by thermal activation enhances surface acidity by the formation of new Brönsted acid sites and the strengthening of other acid sites on the parent zeolite [25-27]. The aim of our work is to evaluate different mordenite (MOR) zeolites (H-MOR, $\mathrm{NH}_{4}-\mathrm{MOR}$, and $\mathrm{Na}-\mathrm{MOR}$ ) and study the effect of doping $\mathrm{H}-\mathrm{MOR}$ with $3.0 \mathrm{wt} \% \mathrm{HCl}, \mathrm{HF}, \mathrm{NH}_{4} \mathrm{Cl}$, and $\mathrm{NH}_{4} \mathrm{~F}$ to visualize this effect on methanol conversion in a flow reactor that operates in a flow of argon at temperatures of $100-300^{\circ} \mathrm{C}$.

\section{Experimental}

\subsection{Preparation of the catalysts}

\subsubsection{H-MOR catalyst}

Received 19 October 2010. Accepted 23 November 2010.

*Corresponding author. Tel: +20-2-22757840; Fax: +20-2-22581243; E-mail: saboulfotouh@hotmail.com

English edition available online at ScienceDirect (http://www.sciencedirect.com/science/journal/18722067). 
The sodium ions in the Na-mordenite zeolite (Zeolon 900-Na, kindly supplied by Norton Co., USA, in the form of $1.59 \mathrm{~mm}$ extrudates) were exchanged five times using an $\mathrm{NH}_{4} \mathrm{NO}_{3}$ solution under reflux. A fresh solution was used each time and the reflux lasted for $8 \mathrm{~h}$ at $70^{\circ} \mathrm{C}$. The zeolite was then separated, washed with distilled water until it was free of $\mathrm{NO}_{3}{ }^{-}$, dried at $110^{\circ} \mathrm{C}$ overnight, and then calcined in air at $550{ }^{\circ} \mathrm{C}$ for $3 \mathrm{~h}$. The H-form (H-MOR) had a $\mathrm{Si} / \mathrm{Al}$ ratio of $6: 1$, a surface area of $470 \mathrm{~m}^{2} / \mathrm{g}$, an effective pore diameter of $0.67 \mathrm{~nm}$, and a pore volume of $0.27 \mathrm{~cm}^{3} / \mathrm{g}$.

\subsubsection{Chlorinated and fluorinated H-MOR catalysts}

Some of the batch zeolite prepared in section 1.1.1 was doped with $3.0 \mathrm{wt} \%$ aqueous $\mathrm{HCl}, \mathrm{HF}, \mathrm{NH}_{4} \mathrm{Cl}$, or $\mathrm{NH}_{4} \mathrm{~F}$, dried and then calcined as mentioned above.

\subsection{Methanol conversion and product analysis}

A silica glass flow tubular reactor system packed with 0.1 $\mathrm{g}$ of the zeolite catalyst was used in all the conversion runs. The reactor was heated in an insulated wider silica tube jacket, which was kept to within $\pm 1{ }^{\circ} \mathrm{C}$. Argon gas was used as a carrier at a flow rate of $30 \mathrm{~cm}^{3} / \mathrm{min}$ in all the runs. The feed (methanol) was introduced into the reactor by continuous evaporation using the argon flow that passed into a closed jar and that was kept at a fixed temperature of $26^{\circ} \mathrm{C}$. The amount of methanol used was always $49.8 \mathrm{mmol} / \mathrm{h}$. The reaction temperatures investigated ranged from $100-300{ }^{\circ} \mathrm{C}$ at $25{ }^{\circ} \mathrm{C}$ increments. The reaction effluent that passed from the reactor was injected into a Perkin-Elmer Autosystem XL gas-chromatograph containing a $4 \mathrm{~m}$ column packed with $10 \%$ squalane on $10 \%$ didecyl phthalate on chromosorp W-HP of 80-100 mesh. A flame ionization detector and the Turbochrom Navigator Program were used for analysis.

\subsection{Characterization of the catalysts}

X-ray diffraction (XRD) patterns of the catalysts were obtained using a Brucker AXS D8 Advance. Patterns were run using a $\mathrm{Ni}$ filter and copper radiation $(\lambda=0.15404 \mathrm{~nm})$ at $40 \mathrm{kV}$ and $40 \mathrm{~mA}$ and at a scan rate of $0.02 \% \mathrm{~min}$.

For temperature-programmed desorption (TPD) of ammonia experiments, we applied the procedures reported by Aboul-Gheit et al. [28] and Aboul-Fotouh [29] using differential scanning calorimetry (DSC) to detect the desorption response of presorbed ammonia from the catalysts. Ammonia was primarily adsorbed on the catalyst in a silica tube furnace. After evacuation at $1.33 \times 10^{-3} \mathrm{~Pa}$ and upon heating at $500{ }^{\circ} \mathrm{C}$ and subsequent cooling under vacuum to $50{ }^{\circ} \mathrm{C}$ ammonia was introduced to the catalyst at a flow rate of 50 $\mathrm{cm}^{3} / \mathrm{min}$. The samples were then assessed in a DSC unit
(Mettler TA-3000) using standard Al crucibles. Presorbed ammonia was desorbed in the DSC cell using dry nitrogen as a purge gas at a flow rate of $30 \mathrm{~cm}^{3} / \mathrm{min}$. The heating rate in the DSC runs was always $10{ }^{\circ} \mathrm{C} / \mathrm{min}$ and the full-scale range was $25 \mathrm{~mW}$.

\section{Results and discussion}

\subsection{Characterization of the catalysts}

\subsubsection{XRD patterns}

Figure 1 shows that none of the main diffraction bands in the XRD patterns obtained for the modified H-MOR show a measurable shift in their $2 \theta$ positions compared to the stock H-MOR sample. However, the diffraction intensities of all the bands decreased for the halogen-modified zeolites. Moreover, the mordenite samples treated by chlorination with $\mathrm{NH}_{4} \mathrm{Cl}$ or hydrochlorination with $\mathrm{HCl}$ gave higher diffraction intensities than those treated by fluorination with $\mathrm{NH}_{4} \mathrm{~F}$ or hydrofluorination with $\mathrm{HF}$ and this can be attributed to a greater extent of zeolite dealumination by the $\mathrm{F}^{-}$ ions than by the $\mathrm{Cl}^{-}$ions $[22,27]$.

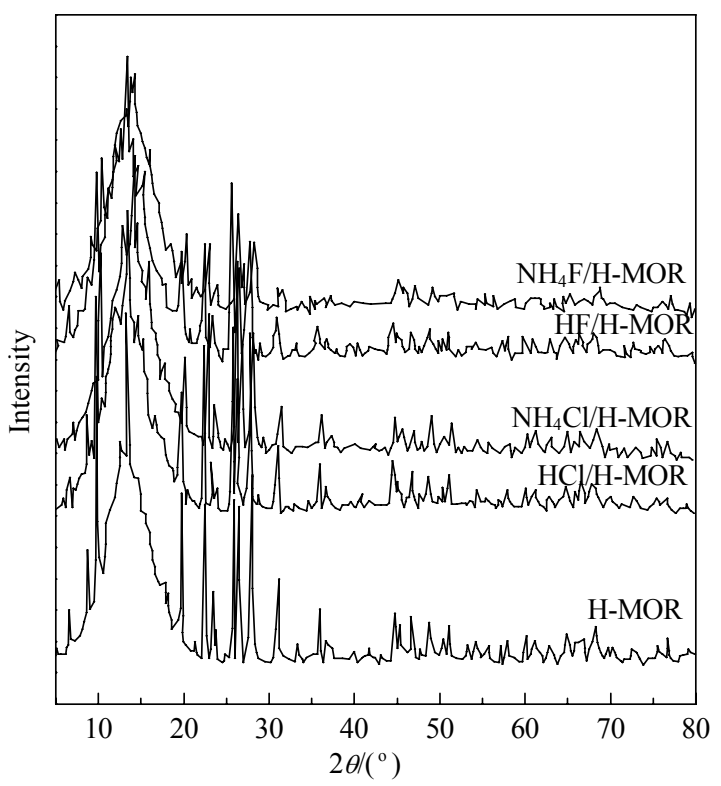

Fig. 1. XRD patterns of the halogenated and hydrohalogenated H-MOR catalysts.

Figure 2 shows that treatment of H-MOR by halogenation or hydrohalogenation leads to a decrease in the degree of crystallinity (crystallite size). The as-synthesized H-MOR was found to have the largest crystallite size among the treated samples and the sizes decreased according to: $\mathrm{H}-\mathrm{MOR}>\mathrm{NH}_{4} \mathrm{Cl} / \mathrm{H}-\mathrm{MOR}>\mathrm{HCl} / \mathrm{H}-\mathrm{MOR}>\mathrm{NH}_{4} \mathrm{~F} / \mathrm{H}-\mathrm{MOR}$ $>\mathrm{HF} / \mathrm{H}-\mathrm{MOR}$.

The stronger attack on the $\mathrm{Al}$ in the zeolite framework is 


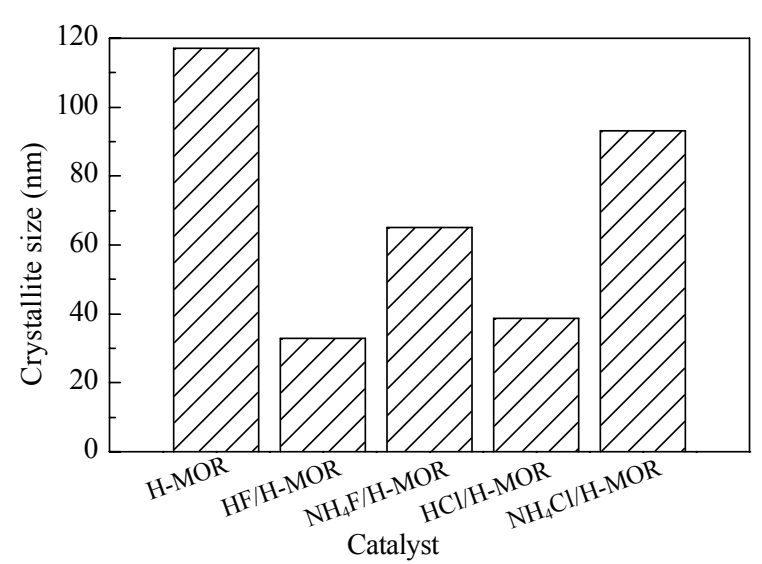

Fig. 2. Crystallite sizes from XRD of the H-MOR zeolite catalysts.

known to be followed by the migration of $\mathrm{Si}$ atoms to fill the vacant $\mathrm{Al}$ positions. Therefore, the $\mathrm{Si}-\mathrm{O}-\mathrm{Al}$ bonds are partially changed to $\mathrm{Si}-\mathrm{O}-\mathrm{Si}$ bonds to stabilize the zeolitic structure. Since $\mathrm{Si}-\mathrm{O}$ bonds are shorter than Al-O bonds, the zeolitic crystal units cells shrink while the channels (pores) and the surrounding crystals become narrower. $\mathrm{F}^{-}$ ions are more reactive than $\mathrm{Cl}^{-}$because of their larger inductive effect [30,31].

\subsubsection{Surface acidity of the catalysts}

TPD of the presorbed ammonia on the acid sites of the catalysts was carried out using DSC with nitrogen as an inert purge gas. TPD profiles for the studied catalysts are given in Fig. 3. Each profile consists of two endothermic peaks, one of which is a low temperature peak (100-300 ${ }^{\circ} \mathrm{C}$ ) that is not related to the activation of carbonium ion formation and, therefore, it cannot be correlated with changes in the catalytic activity during DME formation. The higher temperature peak $\left(400-650{ }^{\circ} \mathrm{C}\right)$ that appears in the thermogram is closely related to carbonium ion formation

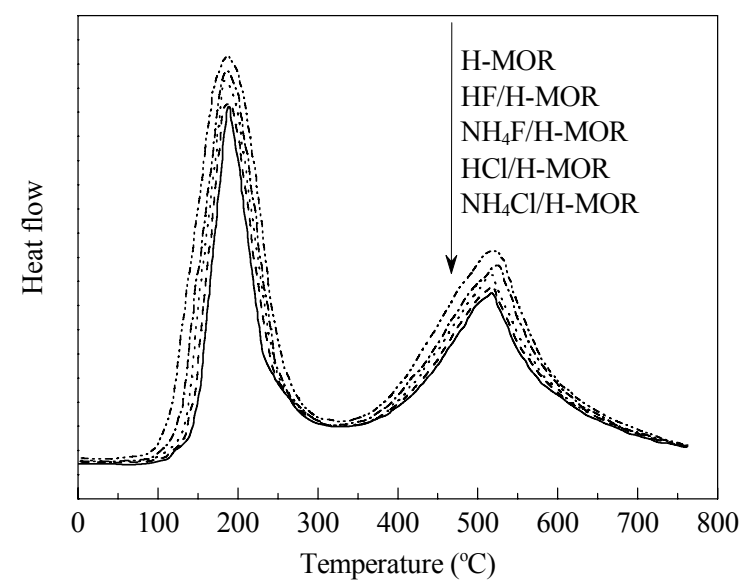

Fig. 3. TPD of ammonia from the untreated and halogenated H-MOR catalysts. and, therefore, to the activity of DME production. This figure shows that the number of acid sites decreases whereas the acid site strength increases with the different treatments (Table 1).

Table 1 HT-ammonia desorption enthalpy, HT-peak temperature, and $\mathrm{Si} / \mathrm{Al}$ ratios for the zeolite catalysts

\begin{tabular}{lccc}
\hline Catalyst & $\Delta H /(\mathrm{J} / \mathrm{g})$ & $\begin{array}{c}\text { HT-peak } \\
\text { temperature }\left({ }^{\circ} \mathrm{C}\right)\end{array}$ & Si/Al ratio \\
\hline H-MOR & 98.3 & 530 & 6.1 \\
$\mathrm{HF} / \mathrm{H}-\mathrm{MOR}$ & 82.2 & 537 & 8.1 \\
$\mathrm{NH}_{4} \mathrm{~F} / \mathrm{H}-\mathrm{MOR}$ & 79.6 & 533 & 7.8 \\
$\mathrm{HCl} / \mathrm{H}-\mathrm{MOR}$ & 74.3 & 535 & 7.3 \\
$\mathrm{NH}_{4} \mathrm{Cl} / \mathrm{H}-\mathrm{MOR}$ & 70.5 & 531 & 6.5 \\
\hline
\end{tabular}

HT: High temperature.

\subsection{Conversion of methanol}

The studied catalysts were prepared to investigate the effect of different mordenite zeolite treatments by the above mentioned halogenation and hydrohalogenation processes. The conversion of methanol was investigated in a fixed-bed reactor using an argon flow of $30 \mathrm{~cm}^{3} /$ min for a reaction temperature range of $100-300{ }^{\circ} \mathrm{C}$ to cover all possible exothermic and endothermic reactions. The major products of the reaction under these experimental conditions were ethylene, propylene, and DME.

\subsubsection{Conversion of methanol with the $\mathrm{H}-, \mathrm{NH}_{4^{-}}$, and Na-MOR catalysts}

The conversion of methanol was examined over the $\mathrm{H}-\mathrm{MOR}, \mathrm{NH}_{4}-\mathrm{MOR}$, and Na-MOR catalysts at $100-300{ }^{\circ} \mathrm{C}$ in a flow reactor. Figure 4 shows the DME and hydrocarbon products that were produced by methanol conversion. The data shows that the dehydration and alkylation products (DME and olefins, respectively) were obtained using $\mathrm{H}-\mathrm{MOR}$ and $\mathrm{NH}_{4}$-MOR whereas only the dehydration product (DME) is produced when using Na-MOR. This is attributed to the absence of strong acid sites, which are capable of promoting olefin formation. Campbell et al. [32] used $\mathrm{CH}_{3} \mathrm{OH}$-TPD for the characterization of the acid properties of the surface zeolite (strength and nature of the acid sites) and concluded that methanol dehydration to DME and the production of light hydrocarbons are related to the type and strength of the acid sites. Brönsted acid sites with moderate to high strengths are responsible for the formation of by-products (e.g. ethylene and propylene) during a reaction between methanol molecules while Lewis acid sites do not show catalytic activity. For the dehydration of methanol to DME, Brönsted and Lewis sites cooperate and the conversion is proportional to the acid strength. 


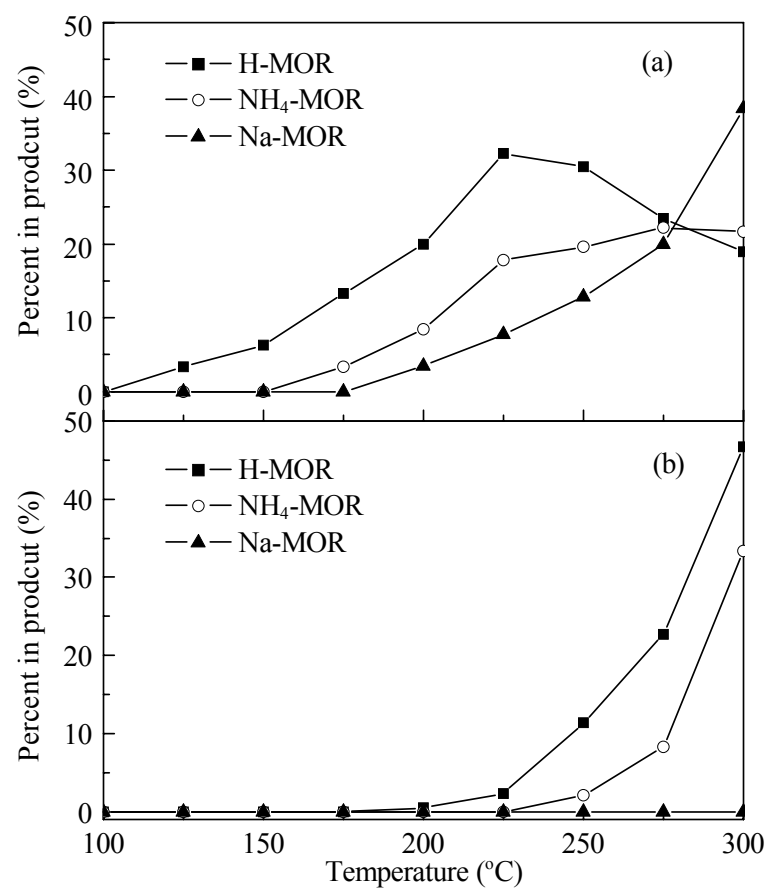

Fig. 4. DME (a) and hydrocarbons (b) in the mordenite catalyst products.

Figure 4 shows the activities of the studied catalysts from 100-300 ${ }^{\circ} \mathrm{C}$ for the conversion of methanol to DME and olefins, respectively. The activity decreases as follows: $\mathrm{H}-\mathrm{MOR}>\mathrm{NH}_{4}$-MOR $>\mathrm{Na}-\mathrm{MOR}$. This order is compatible with the order of mordenite catalyst acidity [28]. From the acid site desorption of $\mathrm{NH}_{3}$ in the Na-MOR and H-MOR Aboul-fotouh [29] indicated that the acidity of H-MOR can be attributed to the strong acid sites whereas the acidity of Na-MOR is due to the weaker acid sites. On the other hand, Aboul-Gheit et al. [28] showed that the acidity of $\mathrm{NH}_{4}$-MOR is lower than that of H-MOR since the acid sites in H-MOR are strong Brönsted sites.

\subsubsection{Conversion of methanol using halogenated and hydrohalogenated H-MOR zeolite catalysts}

Fluorination and chlorination using $\mathrm{NH}_{4} \mathrm{~F}$ and $\mathrm{NH}_{4} \mathrm{Cl}$ with halogen concentrations from 1.0 to $6.0 \mathrm{wt} \%$ has been carried out in previous works [22,23,26,27] and a halogen content of $3.0 \mathrm{wt} \%$ was found to be optimum. Hence 3.0 $\mathrm{wt} \% \mathrm{~F}^{-}$or $\mathrm{Cl}^{-}$was used in this study to prepare the halogenated $\mathrm{H}-\mathrm{MOR}$ zeolite catalysts by $\mathrm{NH}_{4} \mathrm{~F}$ and $\mathrm{NH}_{4} \mathrm{Cl}$ doping. Moreover, hydrohalogenated catalysts were also prepared by doping with $3.0 \mathrm{wt} \% \mathrm{HCl}$ or $3.0 \mathrm{wt} \% \mathrm{HF}$ solutions, respectively.

The prepared halogenated and hydrohalogenated H-MOR catalysts were examined for methanol conversion from 100-300 ${ }^{\circ} \mathrm{C}$. The total methanol conversion activities of the studied H-MOR catalysts doped with $3.0 \mathrm{wt} \% \mathrm{HF}, \mathrm{HCl}$,
$\mathrm{NH}_{4} \mathrm{~F}$, or $\mathrm{NH}_{4} \mathrm{Cl}$, were found to be effective (Fig. 5). Moreover, fluorination and hydrofluorination were found to be more effective than chlorination and hydrochlorination, respectively.

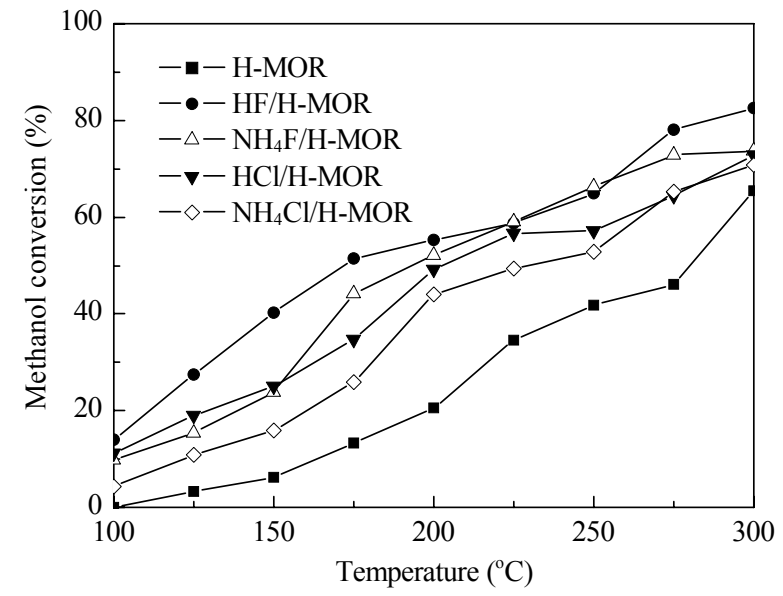

Fig. 5. Total conversion of methanol using the halogenated and hydrohalogenated H-MOR catalysts.

Figure 6 shows that higher activities for methanol conversion to DME were obtained by $\mathrm{F}^{-}$inclusion compared to $\mathrm{Cl}^{-}$inclusion. Moreover, direct acid treatment with $\mathrm{HF}$ or $\mathrm{HCl}$ results in higher activities than that of the corresponding ammonium salt treatments because of direct halogen liberation in the former treatments. The superiority of $\mathrm{F}$ treatment over $\mathrm{Cl}^{-}$treatment is attributed to its higher electronegativity [30,31]. DME production increases as a func-

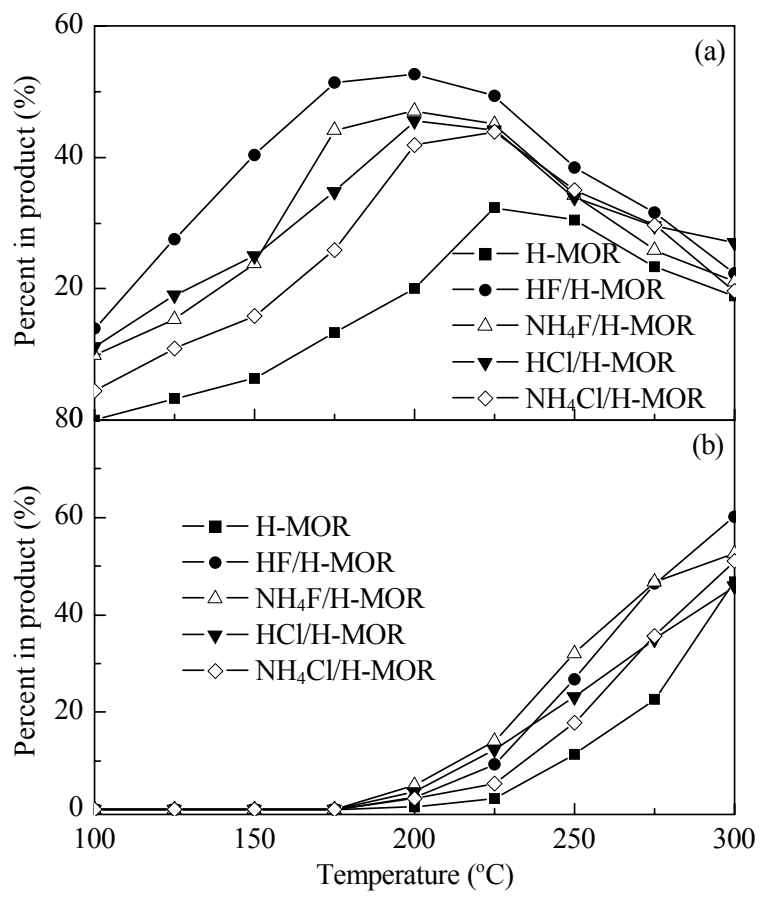

Fig. 6. DME (a) and hydrocarbons (b) in the product upon halogenated and hydrohalogenated H-MOR catalysis. 
tion of reaction temperature up to $200{ }^{\circ} \mathrm{C}$ beyond which DME decreases in the product as the temperature increases further because of hydrocarbon formation (Fig. 6).

The relatively higher activities of all the treated catalysts compared to the H-MOR catalyst are attributed to the higher acid site strengths of the catalysts (Fig. 3 and Table 1). The number of acid sites is expressed by the desorption enthalpy of the pre-adsorbed $\mathrm{NH}_{3}$ from $\mathrm{HF} / \mathrm{H}-\mathrm{MOR}, \mathrm{HCl} / \mathrm{H}-\mathrm{MOR}$, and the H-MOR catalysts and amount to 82.2, 74.3, and $98.3 \mathrm{~J} / \mathrm{g}$, respectively. The acid site strengths as expressed by the desorption temperature were found to be 537, 535, and $530{ }^{\circ} \mathrm{C}$. Additionally, the desorption enthalpies of the pre-adsorbed $\mathrm{NH}_{3}$ from $\mathrm{NH}_{4} \mathrm{~F} / \mathrm{H}-\mathrm{MOR}, \mathrm{NH}_{4} \mathrm{Cl} / \mathrm{H}-\mathrm{MOR}$, and $\mathrm{H}-\mathrm{MOR}$ are $79.6,70.5$, and $98.3 \mathrm{~J} / \mathrm{g}$, respectively. The acid site strengths as expressed by the desorption temperature were found to be 533,531 , and $530{ }^{\circ} \mathrm{C}$, respectively. These data indicate that the fluorination of mordenite increases its acid strength, which is evident from the increased HT-peak temperature determined during $\mathrm{NH}_{3}$ desorption (acid site strength).

Figures 1 and 2 show XRD spectra for the halogenation and hydrohalogenation of the H-MOR catalysts. Evidently, $\mathrm{F}^{-}$and $\mathrm{Cl}^{-}$incorporation into the catalyst results in smaller (nanoscale) H-MOR crystallites, which increases catalyst activities. The decrease in H-MOR crystallinity because of the removal of some $\mathrm{Al}$ from the framework increases the hydrophobicity of the zeolite and its $\mathrm{Si} / \mathrm{Al}$ ratio (Table 1). Corma [33-35] found that the dealumination of zeolites increases their hydrophobicity, which results in a higher capacity for hydrocarbon adsorption and a lower capacity for water adsorption and both these factors are favorable for an increase in activity. Since the dehydration reactions are equilibrium-limited and water is continuously removed from the catalyst surface because of its hydrophobic nature, the catalytic activity of the dealuminated zeolite is greatly enhanced.

\subsection{Activation energy of methanol conversion to DME}

The reaction rate constant was calculated for the different reaction temperatures according to the second-order flow reactor equation $(1)$ :

$$
k=(F / W)[x / a(a-x)]
$$

Where $F$ is the rate of feed injection $49.8 \mathrm{mmol} / \mathrm{h}, k$ is the reaction rate constant, $W$ is the catalyst weight $(0.1 \mathrm{~g}), x$ is the mole fraction of methanol converted to DME, and $a$ is the initial concentration of methanol.

The $E_{\mathrm{a}}$ values for the dehydration of methanol to DME using the studied zeolite catalysts were determined using the Arrhenius equation (2) and the plots are given in Fig. 7.

$$
k=A \exp \left(-E_{\mathrm{a}} / R T\right)
$$

Where $A$ is the pre-exponential factor and $T$ is the absolute

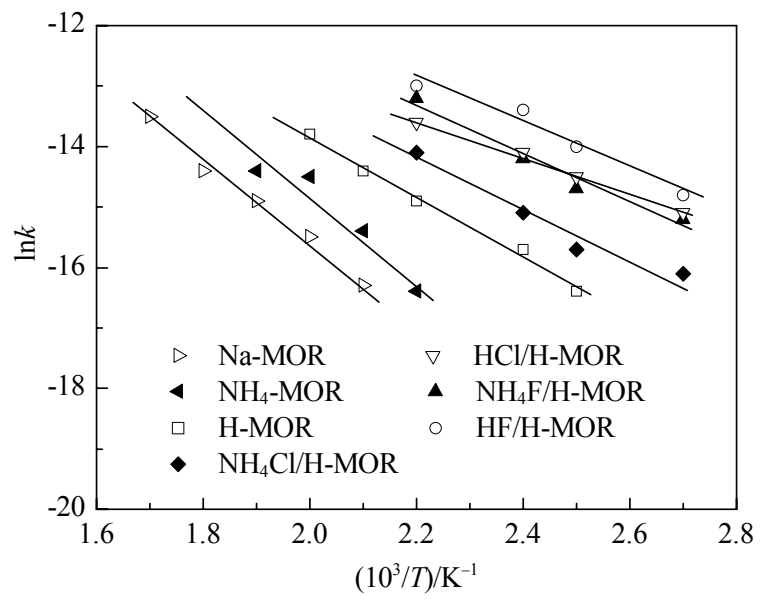

Fig. 7. Arrhenius plot for methanol conversion to DME using treated and untreated mordenite catalysts.

reaction temperature.

The obtained $E_{\mathrm{a}}$ values for methanol dehydration to DME over the studied catalysts are given in Table 2 . The $E_{\text {a }}$ values determined for methanol dehydration to DME generally agree with the activities of the catalysts used. Na-MOR showed lower activity particularly at lower temperatures and, therefore, the $E_{\mathrm{a}}$ value for this catalyst is higher than that of the $\mathrm{NH}_{4}$-MOR and H-MOR catalysts since the latter are more acidic. The treatment of $\mathrm{H}-\mathrm{MOR}$ with $\mathrm{HF}, \mathrm{HCl}$, $\mathrm{NH}_{4} \mathrm{~F}$, or $\mathrm{NH}_{4} \mathrm{Cl}$ results in a decrease in the activation energy $\left(E_{\mathrm{a}}\right)$ of the former catalyst from $41.2 \mathrm{~kJ} / \mathrm{mol}$ before treatment to $21.9,25.2,31.4$, and $35.6 \mathrm{~kJ} / \mathrm{mol}$, respectively, after treatment. This decrease in $E_{\mathrm{a}}$ after halogenation or hydrohalogenation indicates that higher activation results from halogen $(\mathrm{F}, \mathrm{Cl})$ inclusion. Moreover, these values indicate that fluorine is more activating than chlorine.

Table 2 Activation energies for methanol conversion to DME based on the studied catalysts

\begin{tabular}{lc}
\hline Catalyst & $E_{\mathrm{a}} /(\mathrm{kJ} / \mathrm{mol})$ \\
\hline $\mathrm{H}-\mathrm{MOR}$ & 41.2 \\
$\mathrm{NH}_{4}-\mathrm{MOR}$ & 48.7 \\
$\mathrm{Na}-\mathrm{MOR}$ & 56.1 \\
$\mathrm{HF} / \mathrm{H}-\mathrm{MOR}$ & 21.9 \\
$\mathrm{NH}_{4} \mathrm{~F} / \mathrm{H}-\mathrm{MOR}$ & 31.4 \\
$\mathrm{HCl} / \mathrm{H}-\mathrm{MOR}$ & 25.2 \\
$\mathrm{NH}_{4} \mathrm{Cl} / \mathrm{H}-\mathrm{MOR}$ & 35.6 \\
\hline
\end{tabular}

\section{Conclusions}

Na-MOR was found to be the least active catalyst for DME production among a series of studied mordenite catalysts. It was completely inactive toward olefin production because of the lack of Brönsted acid sites. The increase in methanol conversion and the formation of DME on hydrohalogenated H-MOR compared to the halogenated catalysts 
is attributed to the increase in acidity. The higher activity of the halogen treated H-MOR zeolite is attributed to an increase in the $\mathrm{Si} / \mathrm{Al}$ ratio and a decrease in the crystallinity of the current zeolite catalysts. Hydrofluorination treatment was found to be consistently more effective than hydrochlorination treatment.

\section{References}

1 Marchi A J, Forment G F. Appl Catal A, 1993, 94: 91

2 Mikkelson O, Kolboe S. Microporous Mesoporous Mater, 1999, 29: 173

3 Al-Jarallah A M, El-Nafaty U A, Abdillahi M M. Appl Catal A, 1997, 154: 117

4 Stöcker M. Microporous Mesoporous Mater, 1999, 29: 3

5 Freeman D, Wells R P K, Hutchings G J. J Catal, 2002, 205: 358

6 Dubois D R, Obrzut D L, Liu J, Thundimadathil J, Adekkanattu P M, Guin J A, Punnose A, Seehra M S. Fuel Process Technol, 2003, 83: 203

7 Chang C D, Silvestri A J. J Catal, 1977, 47: 249

8 Bjorgen M, Kolboe S. Appl Catal A, 2002, 225: 285

9 Inoue Y, Nakashiro K, Ono Y. Microporous Mater, 1995, 4: 379

10 Tsoncheva T, Dimitrova R. Appl Catal A, 2002, 225: 101

11 Yaragadda P, Lund C R F, Ruckenstein E. Appl Catal, 1989, 54: 139

12 Zaidi H A, Pant K K. In: Proceedings of the 53rd Canadian Chemical Engineering Conference, Hamilton, Ont, 2003. 327

13 Alkhawandeh A, Wu X, Anthony R G. Catal Today, 2003, 84: 43

14 Cañzares P, de Lucas A, Dorado F, Duran A, Asencio I. Appl Catal A, 1998, 169: 137
15 Anwar A, Abdel-Ghaffar A, Aboul-Fotouh S, Ebeid F. Collect Czech Chem Commun, 1994, 59: 820

16 Oh S H, Lee W Y. Korean J Chem Eng, 1992, 9: 37

17 Zaidi H A, Pant K K. Catal Today, 2004, 96: 155

18 Aboul-Fotouh S M K, Hassan M M I. Acta Chim Slov, 2010, 57: 872

19 Freeman D, Wells R P K, Hutchings G J. J Catal, 2002, 205: 358

20 Kang M. J Mol Catal A, 2000, 160: 437

21 Zhu Z, Hartmann M, Kevan L. Chem Mater, 2000, 12: 2781

22 Aboul-Fotouh S M, Aboul-Gheit A K. Appl Catal A, 2001, 208: 55

23 Aboul-Fotouh S M, Aboul-Gheit A K. In: Proceedings of the 9th International Symposium on Heterogeneous Catalysis, Varna, Bulgaria, 2000. 163

24 Arena F, Frusterl F, Mondeller N, Giordano N. J Chem Soc, Faraday Trans, 1992, 88: 3353

25 Le Van Mao R, Le T S, Fairbairn M, Muntasar A, Xiao S, Denes G. Appl Catal A, 1999, 185: 41

26 Aboul-Gheit A K, Aboul-Fotouh S M, Abdel-Hamid S M, Aboul-Gheit N K A. J Mol Catal A, 2005, 245: 167

27 Aboul-Gheit A K, Aboul-Fotouh S M, Abdel-Hamid S M, Aboul-Gheit N K A. Appl Catal A, 2006, 297: 102

28 Aboul-Gheit A K, Abdel-Hamid S M, Ghoneim S A, Al-Owais A A. Erdol Erdgas Kohle, 1999, 115: 90

29 Aboul-Fotouh S M. J Chin Chem Soc, 2003, 50: 1151

30 Hirschler A E. J Catal, 1963, 2: 428

31 Ghosh A K, Kydd R A. Catal Rev-Sci Eng, 1985, 27: 539

32 Campbell S M, Jiang X Z, Howe R F. Microporous Mesoporous Mater, 1999, 29: 91

33 Corma A. Chem Rev, 1995, 95: 559

34 Corma A. Chem Rev, 1997, 97: 2373

35 Corma A, Faraldos M, Martinez A, Mifsud A. J Catal, 1990, 122: 230 